\title{
Resenha \\ Séries americanas são sintoma de quê?
}

\author{
RAFAel Magalhães ANgrisano \\ Cefet-MG - rafael angrisano@hotmail.com \\ Mestrando em Estudos de Linguagens. Especialista em Imagens e Culturas Midiáticas e graduado em Comunicação
Social
}

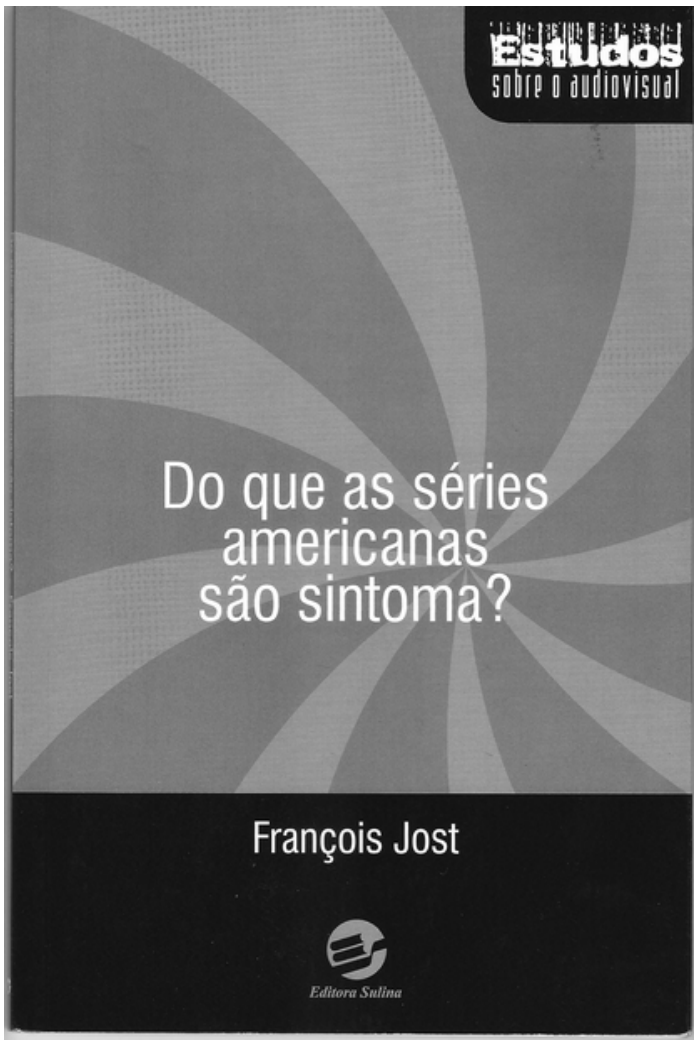

Jost dá início ao livro em tom de lamento. A queixa se justifica pelo fato de as pesquisas francesas que se remetem às séries americanas serem escassas. Apesar disso, o autor enxerga uma mudança de cenário. Para ele, as séries são menos televisuais do que os telejornais, já que costumam ser consumidas também por meio de $\mathrm{TV}$ de recuperação (DVD, streaming, etc.) e, por esse motivo, acabam se elevando ao estatuto de obra (seriam substitutas da sétima arte?) da mesma forma que os filmes.

Esse fato, de algum modo, mostra o respeito adquirido pelas séries na academia, em que os pesquisadores não temem mais demonstrar interesse por esse objeto.

O intuito do autor com a reflexão exposta na obra é compreender o que mantém firme a relação dos telespectadores com a ficção televisual. Por que o interesse? O que ocasiona o consumo? A principal pergunta se expressa no título do livro: Do que as séries americanas são sintoma?

Uma resposta simplória e comum a essas indagações, segundo o próprio Jost, relaciona-se com os segredos de fabricação das ficções televisuais. Essa é uma 
justificativa pela qual as séries norte-americanas superam as francesas em popularidade. No entanto, isso não seria suficiente para explicar por que determinadas ficções nos cativam e outras nos deixam indiferentes. Outra resposta recordada pelo autor é explicitada em uma passagem de Umberto Eco, que fundamenta o sucesso das séries na repetição e na serialidade: as séries acarretam um movimento nostálgico nas pessoas; elas nos fazem lembrar da época em que pedíamos aos nossos pais para que nos contassem infinitas vezes nossa estória favorita.

A hipótese desenvolvida no trabalho é a de que o sucesso das séries norteamericanas é fomentado mais pelo ganho simbólico proporcionado aos telespectadores do que pelos procedimentos de fabricação, que são apenas uma soma de códigos. A questão a ser feita é por que as séries fazem sucesso, refletindo sobre os bens simbólicos que elas vendem, em detrimento da tentativa de encontrar uma resposta no "como" elas são produzidas. O que as séries dizem de seus telespectadores? Qual a familiaridade com a ficção? Esses questionamentos e a hipótese sustentada levaram o autor a se interessar particularmente por pesquisar as séries de maior audiência.

Após os apontamentos iniciais, no segundo tópico do livro, Jost nos conduz a um raciocínio que visa compreender a familiaridade do público com as séries norteamericanas. São citadas três vias que preenchem a ficção de realidade e a realidade de ficção como possíveis válvulas que instigam a identificação fíccional com o nosso cotidiano. A primeira via de acesso à ficção seria a "atualidade", composta por duas faces, a "dispersão" e a "persistência". A dispersão é a credibilidade ficcional ocorrida pela aparição e desaparição de acontecimentos que vemos no mundo dos medias, uma despressurização da ficção e sua absorção pela realidade. A persistência, aqui, possui o sentido de real que persiste, são os acontecimentos que persistem e entram nas tramas, sempre recordados. Como em alguns exemplos citados, temos o fatídico 11 de setembro de 2001, presente nas séries 24 e Prison Break. A segunda via de acesso à ficção é chamada pelo autor de "universidade antropológica". O termo se refere à exploração do que há de humano em nós, ao contrário de modelos psíquicos estáveis e dicotômicos, 
como "bom" e "mau". A terceira via é a que melhor resume as séries norte-americanas, a "midiatização", sintetizada na seguinte passagem: "No mundo das séries, a verdade surge sempre através das imagens: imagens da atualidade que a TV despeja, ou imagens índices que confundem [...]” (JOST, 2012, p. 32).

O terceiro capítulo da obra é uma ponderação acerca da nossa relação com os heróis televisuais. De acordo com o autor, em pesquisas sérias, sempre é registrada a correlação dos telespectadores com os heróis como a causa do sucesso ficcional. Jost se apoia em N. Frye, e seu critério aristotélico da elevação dos personagens, na tentativa de buscar uma possível explanação para o pressuposto. São cinco modos fíccionais para compreensão das séries: o primeiro é o "mítico", no qual os heróis são, por natureza, superiores aos seres humanos. O segundo é o "romanesco", em que os heróis estão um grau acima dos homens e de seu ambiente. No terceiro e quarto casos, temos o modo "mimético alto", em que o herói se parece conosco, mas possui habilidades raras, e o modo "mimético baixo", no qual o herói é igual ao ser humano. Por último, o modo "irônico", com heróis inferiores aos nossos olhos.

Segundo Frye, com o tempo, na literatura, passamos de forma gradual das ficções elevadas para as baixas. Para Jost, o mesmo se pode dizer dos seriados norte-americanos. Essa alteração causa a impressão de maior realismo, pois nos identificamos com os heróis, com suas relações e com suas famílias.

$\mathrm{Na}$ quarta parte do livro, Jost relata sobre a conectividade entre o realismo e a sede de saber dos indivíduos. O realismo, para muitos, é a principal razão de sucesso das séries norte-americanas em comparação com as séries francesas. Não se deve confundir realismo com a tentativa de copiar de modo idêntico o nosso mundo. $\mathrm{O}$ realismo está relacionado à impressão de reconhecimento causada no sujeito fruidor. "O que seduz o telespectador não é, portanto, encontrar a cópia exata do nosso mundo, mas, sim, e sobretudo, um modo de narração, um discurso, com o qual ele está habituado." (JOST, 2012, p. 42). 
De acordo com Hamon, citado pelo autor, o discurso realista é "ostentatório do saber". Ele possui a necessidade de ser o mais transparente que puder, realizando um apagamento do autor para ocasionar no receptor o sentimento de que o relato é uma janela para o real. $\mathrm{O}$ aporte de cognição de uma série realista se desdobra em três domínios do saber: o enciclopédico, o saber-fazer (seriados como Law \& Order e House, nos quais as práticas profissionais são o foco) e o saber-ser (seriados como Ugly Beth e Desperate Housewives, em que os eixos são as personalidades das personagens e comportamentos possíveis em definidas situações).

A criação de um personagem realista tem seu alicerce na vinculação de três papeis (o privado, o profissional e o social). Alguns exemplos de séries e os três papéis são citados no livro: séries centradas na vida privada: Ugly Beth, Sex and City; séries em que o eixo é a vida profissional: House, CSI; séries focadas na sociedade: Prison Break, 24 Horas. Encerrando o capítulo, Jost afirma que o excesso de modelos representacionais da encenação realista faz com que a transparência se perca nos protagonistas das ficções televisuais, ou mesmo em candidatos a programas de reality shows, que caem na mesma lógica.

Finalizando seu fio condutor reflexivo, Jost fala sobre verdades, mentiras e transparência nos seriados e onde encontrá-las. A mentira é considerada algo referencial na sociedade, dentro das séries norte-americanas, como, por exemplo, em Mentalist e Prison Break. O enigma de hoje na ficção é o segredo que oculta o verdadeiro. O acesso ao real está condicionado ao talento do herói de desvendar o âmago interior do outro. “[...] A transparência não pode vir se não de outro lugar como a verdade. Daí a considerar que todas essas séries são o sintoma de uma ideologia que reina no mundo de hoje, a ideologia da transparência, não há se não um passo que eu vou transpor" (JOST, 2012, p. 66).

Mas, afinal, essas séries são mesmo sintoma de nossa época? Consideramos que Jost realizou uma reflexão arguta e competente sobre o assunto. Para o autor, os seriados americanos consolam os sujeitos a partir dessa lógica do verdadeiro e do transparente 
que permanece camuflado, já que vivemos em sociedades democráticas que perdem definitivamente sua transparência. De modo real, essas séries refletem a nossa vida e o nosso mundo, dando-nos uma compensação simbólica.

\section{Referência Bibliográfica}

JOST, F. Do que as séries americanas são sintoma? Porto Alegre: Sulina, 2012

Este artigo e todo o conteúdo da Estudos em Jornalismo e Mídia

estão disponíveis em http://www.periodicos.ufsc.br/index.php/jornalismo/index

Estudos em Jornalismo e Mídia está sob a Licença CreativeCommons 